\title{
Rectal Route of Administration
}

National Cancer Institute

\section{Source}

National Cancer Institute. Rectal Route of Administration. NCI Thesaurus. Code C38295.

The introduction of a substance into the gastrointestinal tract by the way of the rectum, usually for systemic action. Depending on the molecular structure, drugs cross the rectal wall via either intercellular or tight junctions interconnecting the mucosal cells. Drug absorption is usually around $50 \%$ of normal oral dose. Due to the drainage pattern of the rectal veins, the hepatic first-pass effect tends to increase as the dosage form is placed deeper into the rectum. Solid suppositories represent greater than $98 \%$ of all rectal dosage forms. 